\title{
Kadınların Mutfak Güvenliğine ve Yemek Pişirmeye Yönelik Uygulamaları
}

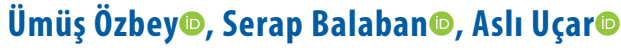

Ankara Üniversitesi, Sağlık Bilimleri Fakültesi, Beslenme ve Diyetetik Bölümü, Ankara,Türkiye

Ümüş Özbey, Arş. Gör. Serap Balaban, Arş. Gör. Aslı Uçar, Doç. Dr.

\section{Illetişim:}

Arş. Gör. Ümüş̧̈zbey

Ankara Üniversitesi, Sağlık Bilimleri Fakültesi, Beslenme ve Diyetetik Bölümü, Ankara/Türkiye Tel: +903123191450

E-Posta:umus_ozbey@hotmail.com
Gönderilme Tarihi : 24 Temmuz 2017

Revizyon Tarihi : : 21 Ağustos 2017

Kabul Tarihi : 21 Ağustos 2017

\section{ÖZET}

Bu çalışma kadınların mutfak güvenliği ve yemek pişirme uygulamalarının belirlenmesi amacı ile planlanmış ve yürütülmüştür. Çalışmaya yaşları ortalama $40,4 \pm 9,8$ olan 300 gönüllü kadın katılmış, veriler anket yöntemi ile toplanmıştır. Kadınlara mutfak güvenliği ve mutfak zekâsı hakkında sorular sorulmuş; bu konulardaki davranış biçimleri ve bilgileri puanlandırılmıştır. Mutfak güvenliğini belirlemek için 'mutfak güvenliği uygulamaları soruları' mutfak zekâsını belirlemek için ise 'mutfak zekâsı uygulamaları soruları' kullanıımıştır. Her iki bölümdeki sorular $5^{\prime}$ li likert tipte olup, bölümlerden alınan toplam puanın yüksek olması mutfak güvenliği ve mutfak zekâsının yüksek olduğunu göstermektedir. Araştırma verilerine göre kadınların mutfak güvenliği ve mutfak zekâsı uygulamalarından aldıkları puanların medeni durum ile ilişkili olmadığı, öğrenim durumu ile ters yönde ilişkili olduğu belirlenmiştir $(p<0,05)$. Araştırmanın mutfak güvenliği ve mutfak zekâsı bölümünde ilkokul mezunları en yüksek puanları alırken (sırasıyla $88,2 \pm 7,9$ ve $43,0 \pm 13,2$ ) üniversite mezunları ve ortaokul mezunları en düşük puanları almıştır (sırasıyla $84,2 \pm 9,4$ ve $39,6 \pm 14,4$ ). Bunun nedeni çalışmadaki eğitim seviyesi yüksek ola bile kadınların çalışma hayatında daha fazla yer almasının ve mutfak güvenliği ile mutfak zekâsı uygulamalarına daha az zaman ayırmaları olabilir.

Anahtar sözcükler: Mutfak güvenliği, mutfak zekâsı, yemek pişirme

\section{PRACTICES FOR WOMEN'S KITCHEN SAFETY AND COOKING}

\section{ABSTRACT}

This work was planned and conducted with the aim of identifying women's kitchen safety and cooking practices. 300 volunteer women with an average age of $40.4 \pm 9.8$ participated in the study and data were collected by questionnaire method. Women were asked about kitchen safety and intelligence; the behavior patterns and information on these topics were scored. 'Kitchen security applications' and 'kitchen intelligence applications' were used to determine their behaviors. Both applications are "likert type" and the high scores on the scales indicate that the kitchen safety and the kitchen intelligence are high. According to the survey data, it is determined that the scores of women's kitchen security and cognitive intelligence practices are not related to the marital status and the educational status ( $p>0.05$ ). While primary school graduates received the highest scores in the kitchen security and kitchen intelligence section of the study (respectively $88.2 \pm 7.9$ and $43.0 \pm 13.2$ ), university graduates and junior high school graduates have the lowest scores (respectively $84.2 \pm 9.4$ and $39.6 \pm 14.4$ ). (The reason is that) (The reason for this is that) or (This is because. .) or (It is because. .) well educated women take more time in working life and spend less time in kitchen security and kitchen practice.

Keywords: Kitchen security, kitchen intelligence, cooking 
$\mathbf{T}$ üm toplumlarda olduğu gibi ülkemizde de temiz besine ulaşım yaşamın devamı ve sağlığın geliştirilmesi için temel faktördür (1). Besin, sağlığa zararlı olması veya tüketime uygun olmaması durumlarında güvenli sayılmamaktadır. Çiftlikten sofraya kadar olan süreçte temiz, bozulmamış ve içinde sağlığa zararlı maddeler bulundurmayanbesingüvenilir besin olarak tanımlanmaktadır (2). Bu durumda en saf tanımıyla besin güvenliği; bir besinin üretim, işleme, saklama, taşıma ve dağıtım aşamalarında besine zarar verebilecek her türlü oluşumun uzaklaştııılması olarak tanımlanmaktadır (3).

Söz konusu evde besin hazırlama hizmeti olduğunda ise, besin güvenliği açısından iki önemli özellik ön plana çıkmaktadır. Bunlardan ilki; besin hazırlama işleminin yapıldığı yerin, kullanılan araç gerecin ve besin hazırlayıcının hijyeni; ikincisi ise hazırlanmış besinlerin uygun koşullarda saklanmasıdır (4). Evde besin hazırlama işleminin çoğunlukla kadınlar tarafından yapıldığı dikkate alındığında ise; kadınların mutfak güvenliği uygulamalarının gerekliliği ve doğruluğu kaçınılmazdır (5).

Günümüzde kadınların çalışma hayatında giderek artan oranda pay alması, toplumların beslenme düzenini değiştirebilmektedir $(6,7)$. Bununla birlikte ülkemizde kadının genişlemiş rolü ne olursa olsun, taşıdığı geleneksel rollerin değeri bütün önemi ve genişliğiyle sürmektedir. Ülkemizde kadının aile içindeki en etkili ve geleneksel rolü aile bireylerini beslemesi şeklindedir (5). Dolayısıyla kadının aile beslenmesine verdiği önem, ayırdığı zaman, aile bireylerinin ve dolayısıyla toplumun fiziksel ve zihinsel yapısını etkilemektedir (8).

Üretimin her aşamasında aktif olarak yer alan kadınlar, aynı zamanda evde besin üretimi yapmakta ve besin maddelerinin satın alımında da belirleyici rol oynamaktadır. Dolayısıyla kadınlar çiftlikten sofraya kadar uzanan besinzincirinde önemli bir yere sahiptir. Kadınların bilinçli üretim ve tüketim davranışlarının yanında besin güvenliğinde temel olarak kabul edilen izlenebilirliğin ve sürdürülebilirliğin sağlanmasında önemli bir paya sahip oldukları ifade edilmektedir (9).

Bu araştırma kadınların mutfak güvenliği ve yemek pişirme uygulamalarının belirlenmesi amacı ile planlanmış ve yürütülmüştür.

\section{Materyal yöntem}

Araştırma evrenini Mersin ve Çorum illerinde bulunan ve çalışmaya gönüllü olarak katılmış kadınlar oluşturmaktadır. Bireylerin belirlenmesinde gelişigüzel örnekleme yöntemi; çalışmaverilerinin toplanmasında ise anket yöntemi kullanılmıştır. Anketin doldurulması yaklaşık on beş dakika sürmüştür. Iç̧erisinde cevaplanmamış ya da birden fazla cevap bulunan anketler araştırmayadâhil edilmemiştir. Toplamda yaşları 22 ile 78 arasında değişen 300 kadın çalışmaya dâhil edilmiştir. Araştırma verilerinin değerlendirilmesinde değişken olarak medeni durum ve öğrenim durumu alınmıştır.

Anket formu; araştırılan konu ile ilgili kaynaklar incelenerek düzenlenmiştir ve 3 bölümden oluşmaktadır. İlk bölümde kadınlara ilişkin demografik bilgiler ile ilgili sorular bulunurken; ikinci bölümde mutfak güvenliği ile ilgili 22, üçüncü bölümde mutfak zekâsı ile ilgili 18 sorubulunmaktadır. Mutfak güvenliği ve mutfak zekâsını belirlemeye yönelik sorular Duyff ve arkadaşlarının (10) Türkçe'ye çevrilmiş olan kitabından faydalanılarak hazırlanmıştır.

Anketinmutfak güvenliği uygulamalarını değerlendirmeye yönelik soruları likert tipi olup; ifadelerdenher zaman' 5 ' , çok sık'4', bazen'3', seyrek'2' ve hiçbir zaman'1' puan olarak değerlendirilmiştir. Konu mutfak güvenliği olduğunda kadınlardan 110 tam puan beklenmekte; alınan puan ne kadar yüksekse mutfak güvenliği o kadar yüksek olarak değerlendirilmektedir. Anketin mutfak zekâsı uygulamalarını değerlendirmeye yöneliksoruları da likert tipi olup; ifadelerden her zaman ' 4 ', çok sık ' 3 ', bazen ' 2 ', seyrek ' 1 ' ve hiçbir zaman ' 0 ' puan olarak değerlendirilmiştir. Bu bölümden 72-51 arası puan alınması mutfak zekâsının yüksek olduğunu, 50-31 arası puan alınması mutfak zekâsının kabul edilebilir düzeyde olduğunu, 30 ve altındaki puanlar isemutfak zekâsınınyetersiz olduğunu göstermektedir.

Çalışmanın mutfak güvenliği bölümü kadınların besin hazırlama ve pişirmedeki hijyen uygulamalarını ve besin kaynaklı hastalıklara yönelik dikkatini ölçmektedir. Mutfak zekâsı bölümü ise yapıldığında beslenme kalitesini arttıran uygulamaların eklenerek; beslenme kalitesini düşüren uygulamalarınçıkarılmasını içermektedir. Yağ oranının azaltılması, meyve-sebzelerin kabuklarının soyulmaması, pişirme süresi, besin çeşitliliğinin arttırılması, baharat ilavesi bunlara örnek olarak verilebilir. Mutfak zekâsı bölümü aslında mutfakta yapılan doğru uygulamalar ile ilgilidir.

Verilerin değerlendirilmesinde SPSS (Statistical Package fort he Social Sciences) paket programından yararlanılmıştır. Normal dağılım gösteren iki grup arasındaki verilerin değerlendirilmesinde "Independent-samples T test", ikiden fazla grup arasındaki verilerin değerlendirilmesinde ise "One-way anova" testi kullanılmıştır. 


\section{Araştırma bulguları}

\section{Genel bilgiler}

Araştırmaya katılan kadınların yaş ortalamaları 40,4 49,8 olup; bunların \%13,7'si 20-29 yaş grubunda, \%37,0'si 3039 yaş grubunda, \%27,0'si 40-49 yaş grubunda ve \%22,3'ü 50 yaş ve üzerindedir. Kadınların \%45,3'üilkokul, \%9,3'ü ortaokul, \%18,7'si lise, \%26,7'siise üniversitemezunudur.

Araştırmaya katılan kadınların \%85,0'i evli, \%15,0'i bekârdır. Kadınların \%56,3'ühayatı boyunca hiç sigara içmemiş, \%19,7'sisigarayı bırakmış, \%24,0'ü ise hala içmeye devam etmektedir. Kadınların \%82,7'si alkol kullanmadığını belirtmektedir.

Çalışan ve çalışmayan kadınların oranı birbirine çok yakın olup, çalışmayanların oranı daha yüksektir $(\% 51,7)$. Kadınların \%74,7'si evde yemeklerini kendi yapmakta olup \%25,3'üise zaman zaman bir yardımcıdan (anne, kayınvalide gibi) yardım almaktadır. Kadınların \%85,3'ü beslenme konusunda bilgili olduğunu düşünmektedir. Bu konuda bilgi sahibi olmadığını belirten kadınların oranı $\% 14,7$ 'dir. Beslenme konusunda bilgi sahibi olduğunu söyleyen kadınlara 'beslenme bilginizi yeterli buluyor musunuz?' sorusu yöneltilmiş; yaklaşık $\% 69,0$ 'u beslenme bilgisini yeterli bulurken, \%31,0'i beslenme bilgisini yeterli bulmadığını belirtmiştir. Beslenme bilgi kaynağı olarak ise en fazla radyo-televizyon ve aile büyükleri gösterilmektedir.

\section{Kadınların mutfak güvenliği uygulamaları}

Tablo 1.'de kadınların mutfak güvenliği ile ilgili uygulamaları yer almaktadır. Katılımcıların \%80,0 ve üzerindeki bir kısmı'ızgara besini masaya getirirken, temiz çatal ve bıçak kullanırım', 'et veya tavuğu kestikten sonra bıçak ve kesme tahtasını temizlerim', 'köfteleri iç kısmındaki pembe renk kayboluncaya kadar pişiririm', 'et, tavuk ve balığı sularının akmayacağı kapların içinde muhafaza ederim' gibi ifadelere her zaman yanıtını vermiştir.

Katılımcıların çoğunluğunun hiçbir zaman yanıtını verdikleri ifadeler ise 'dondurulmuş besinlerin üzerine tarih yazarak muhafaza ederim', 'dondurulmuş yiyecekleri buzdolabında çözdürürüm,' 'et, tavuk ve su ürünlerinde terbiye işlemini buzdolabında yaparım', 'yemek karıştırma kaşığı ile yemeklerin tadına bakarım' (sırasıyla; \%49,3, \%21,0, $\% 24,0, \% 31,3$ ) şeklindedir (Tablo 1).

Tablo 1. Kadınların mutfak güvenliği uygulamalarına yönelik tutum ve davranışları (\%)

\begin{tabular}{|c|c|c|c|c|c|}
\hline & Her zaman & Çok sık & Bazen & Seyrek & Hiçbir zaman \\
\hline 1) Besinlere dokunmadan önce ellerimi sıcak, sabunlu suyla yıkarım & 55,3 & 21,3 & 20,7 & 2,3 & 0,4 \\
\hline 2) Birkaç günde bir bulaşık bezleri ve mutfakta kullandığım giysi, havlu, önlük vb. değiştiririm & 48,7 & 30,3 & 17,0 & 3,7 & 0,3 \\
\hline 3) Fırın içindeki sıçramış yemek artıklarını hemen temizlerim. & 60,7 & 18,0 & 14,3 & 4,7 & 2,3 \\
\hline 4) Her kullanımdan sonra kesme tahtasını klorlu-ağartıcııı bir çözeltiyle temizlerim. & 39,7 & 19,0 & 23,7 & 12,3 & 5,3 \\
\hline 5) Buzdolabını her hafta, tarihi geçmiş veya çok beklemiş eski yiyecekleri atarak temizlerim. & 60,6 & 20,7 & 13,7 & 5,0 & - \\
\hline 6) Dondurulmuş besinlerin üzerine tarih yazarak muhafaza ederim. & 18,7 & 3,7 & 13,3 & 15,0 & 49,3 \\
\hline 7) Dondurulmuş yiyecekleri buzdolabında çözdürürüm. & 35,7 & 13,3 & 17,0 & 13,0 & 21,0 \\
\hline 8) Dondurucu ve dolaplardaki besinleri, eskiler önde olacak şekilde değiştiririm. & 54,3 & 15,0 & 15,7 & 7,0 & 8,0 \\
\hline 9) Konserve besinleri açmadan önce kutunun üzerinde bombelenme akıntı olup olmadığını kontrol ederim & 67,7 & 11,0 & 10,3 & 5,3 & 5,7 \\
\hline 10) Et, tavuk ve su ürünlerinde terbiye işlemini buzdolabında yaparım. & 33,3 & 16,3 & 13,2 & 13,2 & 24,0 \\
\hline 11) Besinleri her tarafı pişecek şekilde ızgara yaparım. & 65,5 & 20,2 & 10,0 & 2,3 & 2,0 \\
\hline 12) Izgara besini masaya getirirken, temiz çatal bıçak kullanııım & 80,7 & 11,7 & 5,0 & 2,0 & 0,6 \\
\hline 14) Yemek karışııma kaşığı ile yemeklerin tadına bakarım. & 31,7 & 11,3 & 21,0 & 4,7 & 31,3 \\
\hline 16) Et ve tavuğu gerekli iç sıcaklık derecelerine kadar pişiririm. & 80,0 & 11,7 & 4,7 & 2,0 & 1,6 \\
\hline 17) Piştikten sonra artan yemekleri 2 saat içinde buzdolabına koyarım. & 56,3 & 25,0 & 14,0 & 4,0 & 0,7 \\
\hline 18) Köfteleri iç kısmındaki pembe renk kayboluncaya kadar pişiririm. & 82,7 & 12,7 & 4,6 & - & - \\
\hline 19) Artan yemekleri tekrar ısıtırken içinden buhar çıkana kadar ateşte tutarım. & 43,0 & 24,7 & 16,0 & 10,3 & 6,0 \\
\hline 20) Izgarayı her kullanımdan sonra temizlerim. & 79,3 & 12,3 & 5,3 & 1,4 & 1,7 \\
\hline 21) Çabuk bozulabilecek yemekleri 2 saat içinde sofradan kaldıııım. & 61,7 & 16,3 & 14,3 & 4,7 & 3,0 \\
\hline 22) Et, tavuk ve balığı sularının akmayacağı kapların içinde muhafaza ederim. & 86,3 & 10,0 & 2,0 & 1,7 & - \\
\hline
\end{tabular}


Çalışmanın mutfak güvenliği bölümünde alınması gereken en yüksek puan $110^{\prime}$ dur. Alınan puan ne kadar yüksek olursa mutfak güvenliği açısından risk o kadar düşük olmaktadır. Çalışma sonucuna göre evli bireyler ortalama $86,1 \pm 9,2$ bekârlar ise $85,8 \pm 10,9$ puan almaktadır. Bireylerin medeni durumlarına göre aldıkları puanlar arasında istatistiksel açıdan fark görülmemektedir $(p<0,05)$ (Tablo 2$)$.

Kadınların mutfak güvenliği puanları ile bireylerin öğrenim durumu karşılaştırıldığında iseen düşük puanı $(84,2 \pm 9,4)$ üniversite mezunlarının, en yüksek puanı ise $(88,2 \pm 7,9)$ ilkokul mezunlarının aldıkları belirlenmiştir $(p<0,01)$ (Tablo 2$)$.

\section{Tablo 2. Mutfak güvenliği uygulamalarına yönelik ortalama puanlar}

\begin{tabular}{|c|c|c|c|c|}
\hline & $n$ & $x \pm s s$ & $f$ & $p^{1}$ \\
\hline \multicolumn{5}{|l|}{ Medeni durum } \\
\hline Evli & 255 & $86,1 \pm 9,2$ & \multirow{2}{*}{7,1} & \multirow{2}{*}{0,65} \\
\hline Bekâr & 45 & $85,8 \pm 10,9$ & & \\
\hline Öğrenim Durumu & & & $\mathbf{p}^{2}$ & farklıık \\
\hline İlkokul & 136 & $88,2 \pm 7,9$ & & \\
\hline Ortaokul & 28 & $84,3 \pm 10,4$ & & \\
\hline Lise & 56 & $84,4 \pm 10,8$ & $4,30,005$ & * $1-3,1-4$ \\
\hline Üniversite & 80 & $84,2 \pm 9,4$ & & \\
\hline Toplam & 300 & $86,1 \pm 9,4$ & & \\
\hline
\end{tabular}

$\mathbf{p}^{1}$ : Man Whitney U test kullanılımıştır. $\mathbf{p}^{2}$ : One Way Anova test kullanıımıştır. Farklılığı belirlenmesinde Tukey testi kullanılmıştır. ${ }^{*} p<0,01$
Tablo 3'te kadınların çalışmanın mutfak zekâsı ile ilgili bölümdeki ifadelere verdikleri yanıtlar yer almaktadır. Katıımcıların yarısından fazlası 'kırmızı et ya da tavuk etinden yağları keserek alırım' $(\% 57,0)$, 'sebze meyvelerin yenilebilir kabuklarını soymadan yalnızca yıkarım' $(\% 65,0)$, 'tavuk etini yemeden önce derisini ayırııım' (\%61,0), 'sebze yemeklerini tencerenin ağzını kapatarak ve çok az su ekleyerek pişiririm' $(\% 72,3)$ şeklindeki ifadelere her zaman yanıtını vermiştir.

Bireylerin büyük bir kısmının hiçbir zaman yanıtını verdikleri ifadeler ise 'makarna, pirinç diğer tahıl ve sebze yemeklerinin sularına tuz eklemeden pişiririm' , 'besinleri şeker yerine meyve, meyve suları ve meyve püreleri ile tatlandırırım', 'yemekleri tuz yerine baharat, limon suyu veya yeşillik ekleyerek lezzetlendiririm', 'tuz katmadan önce yemeğin tadına bakarım' şeklindedir (sırası ile; $\% 44,0, \% 53,3$, $\% 43,0,31,7$ ) (Tablo 3).

Kadınların \%40,3'ü öğünlerde farklı renk ve lezzette besinlerin yer almasına her zaman dikkat etmesine rağmen; süt ürünleri ve sebze ilavesi ile kalsiyum miktarının zenginleştirilmesi gibi uygulamalara sıcak bakmamaktadır. Çorba ve diğer yemeklerde kalsiyum oranı arttırmak için süt gibi malzemeler kullanııım $(\% 35,0)$, salata-çorba ve diğer yemeklere kurubaklagil eklerim $(\% 16,7)$, yemekleri kalsiyumdan zenginleștirmek için üzerine peynir rendelerim $(\% 32,3)$ gibi besinleri zenginleştirme ifadelerine hiçbir zaman yanıtını vermişlerdir (Tablo 3 ).

Tablo 3. Kadınların mutfak zekâsı uygulamalarına yönelik tutum ve davranışları (\%)

\begin{tabular}{|c|c|c|c|c|c|}
\hline & Her zaman & Çok sık & Bazen & Seyrek & Hiçbir zaman \\
\hline 1) Kırmızı et ya da tavuk etinden yağları keserek alııım. & 57,0 & 16,3 & 17,3 & 6,4 & 3,0 \\
\hline 2) Sebze meyvelerin yenilebilir kabuklarını soymadan yalnızca yıkarım. & 65,0 & 12,0 & 17,0 & 4,0 & 2,0 \\
\hline 3) Tavuk etini yemeden önce derisini ayıııım & 61,0 & 11,3 & 14,3 & 7,4 & 6,0 \\
\hline 4) Sebzeleri diri kalacak şekilde az pişiririm. & 41,0 & 7,3 & 27,0 & 10,3 & 14,4 \\
\hline 5) Makarna, pirinç diğer tahıl ve sebze yemeklerinin sularına tuz eklemeden pişiririm. & 19,3 & 13,3 & 15,7 & 7,7 & 44,0 \\
\hline 6) Öğünlerde farklı renk ve lezzette besinlerin yer almasına dikkat ederim. & 40,3 & 26,7 & 16,3 & 10,7 & 6,0 \\
\hline 7) Salata, çorba ve diğer yemeklere kuru baklagil eklerim. & 23,7 & 6,3 & 34,7 & 18,7 & 16,6 \\
\hline 8) Salata, çorba ve sebze yemeklerini kalsiyumdan zenginleştirmek için üzerine peynir rendelerim. & 15,0 & 11,7 & 27,7 & 13,3 & 32,3 \\
\hline 9) Sebze yemeklerini tencerenin ağzını kapatarak ve çok az su ekleyerek pişiririm. & 72,3 & 14,3 & 8,7 & 4,3 & 0,4 \\
\hline 10) Besinleri şeker yerine meyve, meyve suları ve meyve püreleri ile tatlandırıım. & 13,0 & 4,3 & 13,0 & 16,4 & 53,3 \\
\hline 11) Az yağlı yoğurt, et, yağsız et gibi malzemeleri kullanıım. & 38,0 & 9,3 & 16,3 & 18,4 & 18,0 \\
\hline 12) Çorba ve diğer yemeklerde kalsiyum oranını arttırmak için süt gibi malzemeler kullanııı. & 14,7 & 10,7 & 19,6 & 20,0 & 35,0 \\
\hline 13) Piştikten sonra etin yağını ayırııım. & 35,0 & 14,7 & 21,0 & 10,3 & 19,0 \\
\hline 14) Yemekleri tuz yerine baharat, limon suyu veya yeşillik ekleyerek lezzetlendiririm & 19,7 & 8,3 & 14,3 & 14,7 & 43,0 \\
\hline 16) Daha az yağ gerektirecek pişirme yollarını denerim (ızgara, buhar, mikrodalgada pişirme gibi.) & 40,0 & 15,3 & 28,7 & 10,3 & 5,7 \\
\hline 17) Tuz katmadan önce yemeğin tadına bakarım. & 37,0 & 10,6 & 12,7 & 8,0 & 31,7 \\
\hline 18) Çorba, yahni gibi yemekleri hazırlarken yemeklerin haşlama sularını değerlendiririm. & 43,0 & 24,0 & 17,3 & 9,7 & 6,0 \\
\hline
\end{tabular}


Çalışmanın mutfak zekâsı bölümünde evli bireyler ortalama $41,8 \pm 12,4$ puan alırken bekâr bireyler $45,0 \pm 13,4$ puan almıştır $(p>0,05)$. Bireylerin medeni durumu ile aldıkları puan arasında istatistiksel açıdan fark görülmemektedir (Tablo 4).

Bireylerin mutfak zekâsı ile öğrenim durumu karşılaştırıldığında en düşük puanı $(39,6 \pm 14,4)$ ortaokul mezunlarının, en yüksek puanı $(43,0 \pm 13,2)$ ise ilkokul mezunlarının aldıkları görülmektedir ( $p>0,05)$ (Tablo 4).

Kadınların mutfak güvenliği puanları arttıkça mutfak zekâsı puanları artmakta $(r=0,487 ; p<0,01)$ eğitim düzeyi ise azalmaktadır $(r=-0,187 ; p<0,01)$. Mutfak güvenliği puanının yaş ile pozitif yönlü korelasyon gösterdiği belirlenmiştir ( $r=0,271 ; p<0,01)$ (Tablo 5).

Tablo 4. Mutfak zekâsı uygulamalarına yönelik ortalama puanlar

\begin{tabular}{|c|c|c|c|c|}
\hline & $n$ & $x \pm s s$ & $f$ & $p^{1}$ \\
\hline \multicolumn{5}{|l|}{ Medeni durum } \\
\hline Evli & 255 & $41,8 \pm 12,4$ & \multirow{2}{*}{0,4} & \multirow{2}{*}{0,504} \\
\hline Bekâr & 45 & $45,0 \pm 13,4$ & & \\
\hline Öğrenim durumu & & & \multirow{6}{*}{0,1} & $\mathbf{p}^{2}$ \\
\hline İlkokul & 136 & $43,0 \pm 13,2$ & & \\
\hline Ortaokul & 28 & $39,6 \pm 14,4$ & & \multirow{3}{*}{0,515} \\
\hline Lise & 56 & $42,9 \pm 10,2$ & & \\
\hline Üniversite & 80 & $41,1 \pm 13,5$ & & \\
\hline Toplam & 300 & $42,2 \pm 12,6$ & & \\
\hline
\end{tabular}

Tablo 5. Araştırmaya katılan kadınların yaş, eğitim düzeyi, mutfak güvenliği puanı ve mutfak zekası puanı arasındaki ilişkiye ait korelasyon

\begin{tabular}{lcccc} 
Değişkenler & Yaş & $\begin{array}{c}\text { Öğrenim } \\
\text { durumu }\end{array}$ & $\begin{array}{c}\text { Mutfak } \\
\text { güvenliği puanı }\end{array}$ & $\begin{array}{c}\text { Mutfak } \\
\text { zekası puanı }\end{array}$ \\
\hline $\begin{array}{l}\text { Yaş } \\
\text { Öğrenim durumu }\end{array}$ & $1-0,405^{* *}$ & 1 & & \\
$\begin{array}{l}\text { Mutfak güvenliği } \\
\text { puanı }\end{array}$ & $0,271^{* *}$ & $-0,187^{* *}$ & 1 & \\
$\begin{array}{l}\text { Mutfak zekası } \\
\text { puanı }\end{array}$ & 0,051 & $-0,038$ & $0,487^{* *}$ & 1 \\
\hline$* * p<0,01$ & & &
\end{tabular}

\section{Tartışma}

Mutfak güvenliği ve hijyenik besine ulaşım 2000'li yılların başından beri üzerinde sıklıkla durulan ve geleceğinden endişe edilen konulardan biridir (9). Ülkemizde ailenin beslenmesinin büyük ölçüde kadının sorumluluğunda olduğu düşünüldüğünde, kadının mutfak güvenliği ile ilgili uygulamaları büyük bir önem taşımaktadır (5).
Mutfak güvenliği ve mutfak zekâsı ile bireylerin öğrenim durumu karşılaştırıldığında en düşük puanı üniversite mezunları $(84,2 \pm 9,4)$ ve ortaokul mezunları $(39,6 \pm 14,4)$ alırken; en yüksek puanı ilkokul mezunları almıştır (sırasıyla $88,2 \pm 7,9$ ve $43,0 \pm 13,2)$.

Çalışmadaki üniversite mezunu kadınların \%89,0'unun iş hayatında olması; bu nedenle mutfakta daha az zaman geçirmesi besin güvenliğine verdikleri önemi azaltıyor olabilir. Kısıtlı olan zamanın en verimli şekilde kullanımı besin güvenliği uygulamalarının atlanmasına (yemek karıştırma kaşığı ile yemeğin tadına bakılması gibi) neden oluyor olabilir.

Besin işleyicileri arasındaki kişisel hijyen eksikliği, besin kaynaklı hastalıkların oluşmasında en çok rapor edilen durumlardandır. El ve yüzey hijyeni de bu faktörlerdendir (11). Çünkübesinin temas halinde olacağı yüzeylerin ve ellerinhijyenik bir şekilde yıkanması çapraz bulaşmayı engellemede ön koşuldur (12). Bu çalışmada kadınların $\% 55,3$ 'übesinlere dokunmadan önce ellerimi sıcak, sabunlu suyla yıkarım'ifadesine her zaman yanıtını vermiştir. Karakuş ve Küçükkömürler'in (13) çalışmasında kadınların \%85,7'si yiyecek hazırlamadan önce, $\% 84,7$ 'si ise yiyecek hazırlama esnasında ellerini sıcak ve sabunlu su ile yıkadıklarını belirtmişlerdir. Sudershan ve arkadaşlarının (14) anneler üzerinde yaptığı çalışmada ise kadınların $\% 90,0$ 'ından fazlası besin hazırlama ve sunumdan önce ellerini su ile yıkamasına rağmen, sabun kullanarak el yıkayanların oranı oldukça düşüktür $(\% 25,4)$.

Çalışmadaki kadınların \%48,7'sibirkaç günde bir bulaşık bezleri ve mutfakta kullandığım giysi, havlu, önlük vb. değiştiririm'ifadesine her zaman yanıtını vermiştir. Talas ve arkadaşlarının (15) çalışmasında ise kadınların \%45,2'si daima mutfak önlüğü, \%4,1'i ise daima eldiven kullandıklarını belirtmişlerdir. Aynı çalışmada kadınların \%67,1'i mutfakta çalışmaya başlamadan önce saçlarını her zaman örtmektedir. Karakuş ve Küçükkömürler'in (13) çalışmasında ise kadınların \%77,3'ü besin hazırlarken mutfak önlüğü kullanmakta ve \%78,7'si dışarıda giydiği kıyafetlerle mutfağa girmekten mümkün olduğunca kaçınmaktadır.

Mutfağın hijyenik olmaması mutfakta üretilen besinlerin de hijyenik olmaması anlamını taşımaktadır. Bu nedenle besin üretimi esnasında her aşamada mutfak ekipmanları sıcak ve deterjanlı su ile yıkanmalıdır (14). Bu çalışmadaki kadınların \%80,3'ü et veya tavuğu kestikten sonra bıçak ve kesme tahtasını her zaman temizlemektedir; kadınların \%39,7'si ise temizleme işleminde klorlu-ağartıcılı 
çözeltileri kullandığını belirtmiştir. Cömert ve Özel'in (16) çalışmasında ise bireylerin \%46,4'ü 'yiyecek gruplarına göre farklı doğrama tahtası, bıçak vb. kullanırım' ifadesine kesinlikle katılıyorum yanıtını vermiştir. Mahon ve arkadaşlarının (17) çalışmasında et ve sebzeler için ayrı doğrama tahtası kullananların oranının $\% 58,0$ olduğu ve yiyecek doğrama tahtalarının ayrı olması gerektiğine inananların oranının \%74 olduğu belirlenmiştir. Bu çalışmada da kadınların doğru yanıt verme oranları oldukça yüksektir. Ancak yöntemine uygun olarak temizleyip temizlemedikleri sorgulanmamıştır.

Besinlerin genel depolama ilkelerine göre dondurulacak besinler üzerine besinin cinsi ve dondurma tarihi yazılarak etiketlenmelidir (18). Etiketleme ile "ilk giren, ilk çıkar" prensibinin uygulanması ilk önce dondurulan besinin en önce kullanılmasını sağlayarak ürünlerinin raf ömrünün geçmeden tüketilmesini sağlamaktadır (19). Bu çalışmada kadınların \%49,3'üdondurulmuş besinleri muhafaza ederken üzerine tarih yazmamaktadır. Talas'ın (15) yaptığı çalışmada da kadınların çoğunluğunun $(\% 74,4)$ dondurulmuş besinlerin üzerine tarih yazmadıkları saptanmıştır. Yapılan bu uygulama bazı besinlerin olması gerekenden daha uzun süre muhafaza edilmesine yol açabilir.

Dondurulmuş besin kullanılıyor ise bu besinlerin uygun yöntemlerle çözdürülmesi besin hazırlamada önemli bir konudur (18). Bu çalışmada kadınların \%35,7'sidonmuş besinleri her zaman buzdolabında çözdürmekte, \%21,0'i isebu çözme işlemini hiçbir zaman buzdolabında yapmamaktadır. Talas'ın (15) yaptığı çalışmada kadınların \%40,4'ü donmuş eti buzdolabında çözdürmektedir ve bunu izleyen en yüksek oran \%39,6 ile mutfak tezgâhı üzerinde çözdürmedir. Koçak (20)'ın yaptığı çalışmada kadınların \%29,0'unun donmuş etleri dolapta alt rafa indirerek, \%44,7'sinin de dışarıda bekleterek çözdürdükleri saptanmıştır. Besinin uygun şekilde çözdürülmemesi hastalığa sebep olan bakterilerin üremesine yol açabilmektedir (21).

Çalışmadaki kadınların çoğunluğu $(\% 81,3)$ piştikten sonra artan yemekleri 2 saat içinde buzdolabına koymaktadır. Çalış'ın (22) yaptığı benzer çalışmada ise ilçe ve köylerdeki kadınların sırayla \%90,0 ve \%96,4'ünün pişmiş yemekleri soğuduktan sonra buzdolabına koydukları belirlenmiştir. Cömert ve Özel'in çalışmasında da (16) bireylerin 40,8'ipişmiş yiyecekleri 2 saatten fazla oda sıcaklığında bırakmadığını ifade etmiştir. Bu doğru bir uygulama olup, daha uzun süre bekletmelerde Clostridium perfringenskaynaklı besin zehirlenmeleri görülebilmektedir (17).

Yemeklerin tat kontrolleri yemeklerin karıştırıldığı kaşık ile değil, ayrı bir kaşık ile bir tabağa koyarak yapılmalıdır (19). Bu çalışmada kadınların \%31,7'si yemek karıştırma kaşığı ile yemeklerin tadına bakmaktadır. Baş ve Sağlam'ın (23), otel personelleri üzerinde yaptıkları bir çalışmadapersonelin $\% 75,0^{\prime} i$ tat kontrolünün tabağa konup kasık ile yapılmasının, \%17,9'u tencere içinden kaşığa alınarak yapılmasının uygun olacağını belirtmiştir. Bu uygulama çapraz kontaminasyonu engellemek ve yemeği pişiren kişideki mikroorganizmaların (Staphlylococcus aureus gibi) besine geçişini engellemek için oldukça önemlidir (19).

\section{Sonuç ve öneriler}

Çalışmada hem medeni durum hem öğrenim durumu değişkenlerine göre alınan puanlarda yetersizlik söz konusudur. Mutfak güvenliği ve mutfak zekâsı bölümünde ilkokul mezunu kadınlar en yüksek puanları alırken, üniversite ve ortaokul mezunları en düşük puanları almıştır. Çalışmadaki üniversite mezunu kadınların birçoğunun iş hayatında olduğu düşünüldüğünde; bu kadınlara mutfakta zaman yönetimi ve kontrolünü arttıran eğitimler verilebilir.

Kadınların mutfak güvenliği ile ilgili uygulamalarının yetersiz olması; hem kendilerinin hem de yemek sunduğu kişilerin besin kaynaklı hastalıklara yakalanma riskini artırmaktadır. Mutfak zekâsı ile ilgili uygulamalarının yetersiz olması ise beslenme kalitesini düşürerek yetersiz beslenmeye yol açabilmektedir. Buna göre çalışmadaki kadınların mutfak güvenliği ve mutfak zekâsı uygulamalarında aldıkları puanların yetersizliği göz önüne alınarak bilgilendirilmesi gerekmektedir. Doğru pişirme uygulamalarının gerekliliği dikkate alındığında, bu hedef kitleye yönelik eğitim faaliyetlerinin yerinde olacağı açıktır. Kadınlar üzerinde yürütülen eğitimlerde besin güvenliğimi ve beslenme kalitesini arttıran konulara ağırlık verilmelidir. 


\section{Kaynaklar}

1. WHO, Risk Communication Applied to Food Safety; 2015. http:// www.who.int/foodsafety/en/ Erişim 14.01.09.2019.

2. FAO, WHO. Strengthening National Food Control Systems: Guidelines To Assess Capacity Building Needs. Food and Agriculture Organization and World Health Organisation, Rome 2006. http:// www.fao.org/3/a-a0601e.pdf Erişim 14.01.09.2019.

3. Hopper M, Boutrif E. Strengthening national food control systems: guidelines to assess capacity building needs. Food \& Agriculture Organisation, 2006. http://www.fao.org/ sustainable-food-value-chains/library/details/en/c/265856/

4. Sert TŞ, Bilgin B. Edirne Merkezindeki Hastanelerin Mutfak ve Personel Hijyeninin Belirlenmesi. Türkiye 10. Gıda Kongresi Derg 2008;1061-4.

5. Kılıç E, Şanlıer N. Üç Kuşak Kadınının Beslenme Alışkanlıklarının Karşılaştırılması. Kastamonu Eğitim Derg 2007;15:31-44.

6. Dölekoğlu C. Tüketicilerin İşlenmiş Gıda Ürünlerinde Kalite Tercihleri, Sağlık Riskine Karşı Tutumları ve Besin Bileşimi Konusunda Bilgi Düzeyleri (Adana Örneği). Doktora Tezi. Adana; Çukurova Üniversitesi Fen Bilimleri Enstitüsü; 2002.

7. Baysal A. Sosyal Eşitsizliklerin Beslenmeye Etkisi. C. Ü. Tıp Fakültesi Derg 2003;25:66-72.

8. Uyar A. Konya II Merkezi Kamu Kuruluşlarında Çalışan Kadınların Beslenme Alışkanlıkları Ve Bilgi Düzeyleri Üzerine Bir Araştırma. Yüksek Lisans Tezi Ankara; Ankara Üniversitesi Fen Bilimleri Enstitüsü; 1997.

9. Uzunöz M, Gülşen M. Üniversite Öğrencilerinin Süt ve Süt Ürünleri Tüketim Alışkanlıklarının Belirlenmesi. Gıda Teknolojileri Elektronik Derg 2007;3:15-21.

10. Duyff RL. Food \& Nutrition Guide. New York: The American Dietetic Association; 1998. pp.303-26.

11. WHO (World Health Organization). 10 Facts on Obesity; 2016. http://www.who.int/features/factfiles/obesity/en/ Erişim Tarihi: 14.01.09.2019

12. Marzano MA, Balzaretti C. Cook-Serve Method in Mass Catering Establishments: Is it Still Appropriate to Ensure A High Level of Microbiological Quality and Safety? Food Control 2011;22:1844-50. [CrossRef]
13. Karakus S, Kucukkkomurler S. The Application of Women Towards Food Safety. TAF Prev Med Bull 2012;11:651-60. [CrossRef]

14. Sudershan RV, Rao GS, Rao P, Rao MV, Polasa K. Food Safety Related Perceptions and Practices of Mothers -a Case Study in Hyiderabad, India. Food Control 2008;19:506-13.

15. Talas C, Ucar A, Ozcelik O. Women Food safety practices from shopping to eating in Ankara. Pakistan J Nutr 2009;8:1422-9. [CrossRef]

16. Cömert M, Özel K. Otel işletmelerinde hijyen ve sanitasyon kuralarının mutfak personeli tarafından bilinirlik ve uygulanma düzeyi. ASOS - Akademik Sosyal Araştırmalar Derg 2015;3:310-22.

17. Mahon D, Cowan C, Henchion M, Fanning M. Food-Handling Practices of Irish Beef Consumers. J Food Safety 2006;26:72-81. [CrossRef]

18. Bilici DS, SB Temel Sağlık Hizm Gen Müd, Uyar MA, Beyhan Y, Sağlam F, Hacettepe Üniv Sağlık Bil Fak Beslenme ve Diyetetik Böl. Besin Zehirlenmeleri, Nedenleri ve Korunma Yolları. Ankara: Klasmat Matbaacılık; 2008. ss.7-18.

19. Bilici S, SB Temel Sağlık Hizm Gen Müd, Uyar F, Beyhan Y, Sağlam F, Hacettepe Üniv Sağlık Bil Fak Beslenme ve Diyetetik Böl. Besin Güvenliği. T.C. Sağlık Bakanlığı Temel Sağlık Hizmetleri Genel Müdürlüğü Beslenme ve Fiziksel Aktiviteler Daire Başkanlığı Beslenme Bilgi Serisi, Ankara: Klasmat Matbaacılık; 2008.

20. Koçak H. Yiyecek Hazırlama ve Pişirme Uygulamaları -Amasya Örneği. Karadeniz Sosyal Bilimler Derg 2012;4:13-23.

21. Ersin M, Beyhan Y. Toplu Beslenme Sistemlerinde Hijyen Sanitasyonu Sağlama Önerileri.TTB Mesleki Sağlık ve Güvenlik Derg 2001;8:19-26.

22. Çalış C. Milas İlçesi Ve Köylerinde Ailelerin Beslenme Alışkanlıkları. Yüksek Lisans Tezi. Ankara; Fen Bilimleri Enstitüsü Ev Ekonomisi Anabilim Dalı; 2005.

23. Baş M, Sağlam F. Otel Beslenme Servis Personelinin Kişisel ve Çevre Hijyen Bilgisinin Ölçülmesi. Beslenme ve Diyet Derg 1997;26:28-32. 